\title{
MENGEMBANGKAN IKLIM ORGANISASI DI SEKOLAH DENGAN MENGGUNAKAN MODEL TAGIURI
}

\author{
Imam Wahyono \\ Institut Agama Islam Ibrahimy, Banyuwangi, Indonesia \\ Email : imamwahyono12031989@gmail.com
}

DOI: http://doi.org/10.33650/al-tanzim.v3i2.638

\begin{tabular}{l|l|l} 
Received: Agustus 2019 & Revised: Oktober 2019 & Approved: November 2019 \\
\hline
\end{tabular}

\begin{abstract}
:
Organizational Climate is a subjective perception about the condition of a person in an organization that is sustainably maintained by involving all stakeholders, so that organizational goals can be achieved effectively and efficiently. If the organizational climate setting in an institution is positive, then the vision, mission and goals which are the ideals of the school will be effectively achieved. This research uses research library type research. The data analysis technique uses content analysis. Based on the results of research conducted by experts, including Tagiuri, argues that in developing the organizational climate in schools, there are four dimensions namely the ecological or environmental dimension, the social dimension, the social system and the culture that surrounds it. These four dimensions according to Taguiri include all dimensions in educational institutions to achieve the goals of the organization of educational institutions. Among the strategies that can be used to develop a positive organizational climate through these four dimensions, namely by making a policy or regulation by the Principal, where the policy leads to the improvement of organizations that are oriented to quality.
\end{abstract}

Key words : Climate Organizations, Schools, Tagiuri Models

\begin{abstract}
Abstrak
Iklim Organisasi merupakan persepsi subjektif tentang kondisi seseorang dalam suatu organisasi yang dipertahankan secara berkelanjutan dengan melibatkan semua pemangku kepentingan, sehingga tujuan organisasi dapat tercapai secara efektif dan efisien. Jika iklim pengaturan organisasi dalam suatu lembaga positif, maka visi, misi dan tujuan yang merupakan cita-cita sekolah akan tercapai secara efektif. Penelitian ini menggunakan jenis penelitian library reseach. Teknik analisis datanya menggunakan konten analisis. Berdasarkan hasil penelitian yang dilakukan oleh para ahli, di antaranya Tagiuri, berpendapat bahwa dalam mengembangkan iklim organisasi di sekolah, terdapat empat dimensi yaitu dimensi ekologis atau lingkungan, dimensi sosial, sistem sosial dan budaya yang mengitarinya. Empat dimensi ini menurut Taguiri mencakup semua dimensi di lembaga pendidikan untuk mencapai tujuan organissasi lembaga pendidikan. Di antara strategi yang bisa digunakan untuk mengembangkan iklim organisasi yang positif melalui empat dimensi tersebut, yaitu dengan dibuatkannya kebijakan atau regulasi oleh Kepala Sekolah, di mana kebijakan tersebut mengarah kepada perbaikan organisasi yang beorioentasi pada mutu.
\end{abstract}

Kata Kunci : Iklim Organisasi, Sekolah, Model Tagiuri 


\section{PENDAHULUAN}

Iklim organisasi di setiap lembaga organisasi pasti mengalami perbedaan. Keanekaragaman itu terjadi karena sejak awal pekerjaan tersebut didesain berdasarkan organisasi atau kondisi psikis yang dimiliki oleh para pekerja, dari situlah perbedaan suatu organisasi terbentuk. Pada dasarnya, perbedaan organisasi merupakan warna bagi anggota suatu organisasi (Muhammad Husni, 2018), meskipun warna tersebut sebetulnya terbentuk juga dari peranan seorang pemimpin organisasi dan tujuan organisasi. Untuk mencapai tujuan organisasi yang telah ditetapkan, semua elemen yang berada di dalam organisasi harus terlibat. Dari kegiatan organisasi tersebut, terbentuklah kebiasaan dan sesuatu yang menjiwai organisasi itu, diantaranya adalah iklim organisasi (Yukl, 2015).

Dalam ilmu organisasi, Iklim organisasi dan iklim komunikasi memiliki keterkaitan yang sangat berarti. Menurut Redding (1972), kedua konsep ini adalah strategi di mana manajemen berupaya membangun untuk menciptakan organisasi yang efektif, khususnya dengan cara memberdayakan karyawan melalui kepuasan kerja. Sementara itu, iklim organisasi sendiri termasuk dalam aspek komunikasi keorganisasian, khususnya komunikasi manajerial.

Dalam An Interpretive Review of Theory and Research, Redding (1972) secara tegas menyatakan: "The climate of the organization is more crucial than are communication skills or techniques (taken by themselves) in creating an effective organization". Iklim organisasi merupakan hal yang urgen dan harus memegang peranan kunci dalam penciptaan organisasi yang efektif.

Iklim sekolah memiliki empat perspektif: keterbukaan perilaku, kesehatan hubungan interpersonal, kesehatan dan keterbukaan, dan perilaku masyarakat guru. Keempat perspektif tersebut: membedakan antara sekolah yang satu dengan sekolah yang lain; memiliki hubungan positif, memiliki dampak penting organisasi seperti moral warga sekolah, mutu dan efektivitas sekolah (Hoy, K. W., 2001).

Salah satu peneliti tentang iklim sekolah Hoy, K. W. (2001) mencatat bahwa iklim sekolah yang positif mempengaruhi efektivitas sekolah secara keseluruhan. Dengan kata lain, ini menyiratkan bahwa ada hubungan antara iklim positif di sekolah dan keefektifannya. Halpin dan Croft sebagaimana dikutip Tubbs (2008) menyatakan bahwa persepsi siswa dan masyarakat tentang sekolah penting untuk menciptakan iklim yang baik, di mana guru dapat memiliki pengajaran yang berkualitas, siswa mencapai hasil sesuai dengan ambisi, dan orang tua terlibat dalam pendidikan anak-anak mereka.

Untuk mencapai itu semua, tentunya intervensi pemimpin pendidikan memiliki peran yang sangat penting. Diantaranya adalah meningkatkan tingkat kepuasan guru secara keseluruhan difokuskan pada ; Penetapan kriteria yang jelas untuk penilaian, pengangkatan dan promosi guru berdasarkan kinerja kerja yang baik dari semua orang, Pelengkapan sekolah dengan alat pengajaran lengkap yang diperlukan untuk menjamin proses pembelajaran. Agar supaya 
Al-Tanzim : Jurnal Manajemen Pendidikan Islam E-ISSN: 2549-5720 P-ISSN: 2549-3663

Vol. 03 No. 02 (2019) : 61-72

https:// ejournal.unuja.ac.id/index.php/al-tanzim

pembelajaran berjalan efektif dan efisien, iklim harus ramah tidak hanya antara siswa tetapi juga antar guru karena belajar akan lebih menyenangkan dan efektif jika lingkungannya lebih ramah bermusuhan.

Berangkat dari hal tersebut, maka peneliti tertarik untuk meneliti tentang pengembangan iklim organisasi di sekolah melalui model Tagiuri. Hal tersebut memiliki keunikan dan kebaruan/novelty bila dibandingkan dengan penelitian yang ada, mengingat model Tagiuri merupakan hal yang baru ketika diimplementasikan dalam dunia pendidikan.

\section{Konsep Dasar Iklim Organisasi}

Robbins (1996) mendifinisikan organisasi sebagai kesatuan sosial yang dikoordinasikan secara sadar dengan suatu batasan yang relatif dapat diidentifikasi, relatif bekerja terus menerus untuk mencapai tujuan tertentu. Sedangkan pengertian organisasi menurut Blanchard Kneth and Hersey Paul (1988) adalah suatu sistem sosial yang terdiri atas sub sistem manusia, sub sistem teknologi, sub sistem informasi, dan sub sistem administrasi. Dari pendapat ahli tersebut, dapat dijelaskan bahwa organisasi merupakan kumpulan sistem atau sub sistem yang memiliki keterkaitan dan menyatu sebagai wadah untuk mencapai tujuan tertentu (Griffin, 2013).

Selanjutnya, Iklim organisasi seperti yang dinyatakan oleh Gibson (2009) merupakan serangkaian sifat lingkungan kerja yang dinilai langsung ataupun tidak langsung oleh karyawan, yang dianggap menjadi kekuatan utama dalam mempengaruhi perilaku karyawan.

Hoy, K. W. (2001) mengemukakan bahwa : Organization climate is a relatively enduring quality of school environment that experience by teachers affect their behavior, and is besed om their collective perpection of behavior in school. A climate emerges through the interaction of members and exchange of sentiment omong them. The climate of a school is its "personality". Beliau menyatakan bahwa iklim organisasi adalah kualitas lingkungan sekolah yang berlangsung secara relatif yang dialami oleh pendidik dalam mempengaruhi sikap dan itu berdasarkan kepada kepentingan secara bersama tentang "sikap" di sekolah. Iklim terjadi melalui interaksi dari anggota dan pertukaran perasaan di antara mereka. Iklim organisasi sekolah adalah kepribadianya.

Sementara itu, Tagiuri sebagaimana dikutip oleh David (2003) mendefinisikan iklim organisasi sebagai berikut: Organizational climate is a relatively enduring quality of the internal environment of an organization that (a) is experienced by its members, (b) influences their behavior, and (c) can be described in terms of the values of a particular set of characteristics (or attributes) of the organization. Iklim organisasi adalah kualitas yang berlangsung secara kontinu di dalam lingkungan internal organisasi yang dialami oleh karyawannya, berpengaruh terhadap perilaku karyawannya, dan dapat dijelaskan dalam hal nilai-nilai dari seperangkat karakteristik tertentu (atau atribut) dari organisasi. 
Tagiuri (1968) berpandangan bahwa iklim organisasi sebagai seperangkat persepsi (a set of perception variables) yang hadir sebagai impact utama dari organisasi. Dalam pengertian, beliau menjelaskan bahwasanya kualitas yang terjadi dalam suatu lingkungan internal organisasi dialami oleh para pekerjanya. Artinya, kualitas dalam statemen tersebut adalah hasil suatu proses pengalaman subyektif yang terjadi pada masing-masing pekerja, bukan suatu deskripsi tentang keadaan obyektif yang secara bersamaan terjadi bagi semua karyawan. Selanjutnya pengalaman subyektif pekerja itu memiliki dampak terhadap perilaku tentang bagaimana pekerja tersebut melaksanakan tugas/pekerjaannya dan berperilaku di dalam organisasi. Akhirnya, perilaku pekerja tersebut merupakan hasil persepsi mengenai lingkungan kerja, dan simpulan dari perwujudan nilai-nilai yang merupakan ciri khas organisasi.

Dengan demikian, iklim organisasi dapat didefinisikan sebagai suasana lingkungan, baik lingkungan fisik maupun lingkungan sosial pekerjaan yang dapat dirasakan oleh orang-orang yang terlibat di dalam proses pembelajaran, baik langsung atau tidak langsung, yang tercipta akibat kondisi kultural organisasi tersebut (Haryani, 2017). Iklim ini sifatnya relatif abadi di internal organisasi, yang mana langsung dialami oleh anggotanya, berpengaruh terhadap perilaku pegawainya, dan dapat dijelaskan dari seperangkat karakteristik tertentu dari organisasi (Kiki Cahaya Setiawan Prodi, 2015).

Untuk menciptakan iklim organisasi, diperlukan hubungan sosial yang harmonis antara sesama pekerja. Hubungan sosial ini berupa komunikasi vertikal maupun horizontal, kerjasama karyawan saat bekerja, supervisi, dukungan dari bawahan, dan kejelasan tugas yang diemban oleh para pekerja. Dengan kata lain, iklim organisasi merupakan nilai-nilai, kepercayaan, tradisi, dan asumsi yang diberikan kepada para karyawan, baik yang diekspresikan maupun yang tidak diekspresikan.

Dalam hal pengukuran iklim organisasi, hanya dapat dideskripsikan dan diukur secara tidak langsung melalui persepsi para anggota dalam suatu organisasi. Secara faktual, iklim organisasi selalu ada dalam setiap organisasi. Pada umumnya iklim organisasi berakibat pada setiap karyawan dan setiap pekerjaan yang mereka lakukan, di mana setiap individu dapat pula mempengaruhi iklim organisasi.

Untuk menjaga iklim organisasi yang kondusif, maka dalam melakukan eksplorasi, menjelajahi ide baru maupun cara baru, perlu disesuaikan dengan kreatifitas. Luthans (1995) mengemukakan bahwa iklim organisasi merupakan suatu keseluruhan perasaan yang disampaikan melalui tata ruang fisik, cara peserta saling berhubungan, dan cara anggota organisasi melakukan pendekatan diri dengan pelanggan atau orang lain/luar.

Berbagai peneliti dan reformis pendidikan mengidentifikasi iklim sekolah dengan cara yang berbeda, tetapi tampaknya ada konsensus tentang apa yang membentuk iklim sekolah. Freiberg dan Stan sebagaimana dikutip oleh Rapti (2013) mengatakan bahwa iklim sekolah adalah hati dan jiwa sebuah 
Al-Tanzim : Jurnal Manajemen Pendidikan Islam E-ISSN: 2549-5720 P-ISSN: 2549-3663

Vol. 03 No. 02 (2019) : 61-72

https:// ejournal.unuja.ac.id/index.php/al-tanzim

sekolah serta faktor yang memberikan motivasi kepada siswa dan guru sehingga mereka berkeinginan dan bersedia berada di sana setiap hari. Iklim adalah kepribadian suatu organisasi dan iklim organisasi mirip dengan kepribadian individu.

Berangkat dari hal tersebut, dapat dipahami bahwa iklim sekolah ada hubungannya dengan atmosfer atau perasaan yang berlaku di sekolah tertentu. Iklim organisasi muncul dari hubungan antara pemimpin dan guru, guru dan siswa dan antara pemimpin dan siswa. Sekolah sebagai sistem interaksi sosial memaksa para pemimpin, guru dan siswa untuk berinteraksi dalam bidang perencanaan, pengambilan keputusan, dan penyelesaian masalah di tingkat administratif. Mereka juga berinteraksi pada masalah-masalah pribadi yang merupakan bagian dari rutinitas sekolah normal.

\section{Jenis-Jenis Iklim Organisasi}

Iklim organisasi yang satu dengan yang lain berbeda-beda. Banyak faktor yang menentukan perbedaan masing-masing iklim organisasi tersebut, dan keseluruhannya dianggap sebagai kepribadian atau iklim suatu organisasi. Menurut Halpin dan Don B. Croft sebagaimana dikutip oleh Burhanuddin (1994) membedakan berbagai jenis iklim yang ada di sekolah, termasuk iklim terbuka, iklim terkontrol, iklim otonom, iklim ayah, iklim keluarga, dan iklim tertutup.

Iklim terbuka berkaitan dengan karakteristik ekspresifnya. Iklim terbuka dapat dengan mudah digunakan untuk memperhitungkan ruang dan keaslian antara hubungan kepala sekolah, guru, siswa dan orang tua. Hoy, K. W.(2001) berpendapat bahwa iklim terbuka merefleksikan peran yang suportif, ramah dan positif dari kepala sekolah (manajer) terhadap ide-ide guru serta keterikatan dan pengabdiannya untuk bekerja. Menurutnya, iklim sekolah terbuka tidak dapat terjadi dalam semalam, yang seharusnya merupakan hasil dari rekayasa pengembangan yang baik dan dilaksanakan antara guru dan kepala sekolah. Itu juga hasil dari kebijakan perekrutan yang kuat yang harus dicirikan oleh instrumen kepribadian yang baik

Iklim Terkontrol memiliki karakteristik dengan cara mengandalikan pada saat kerja. Meskipun dalam hal ini kepala sekolah jauh dari model dedikasi, pentingnya diberikan pada pencapaian tugas dan sedikit waktu dikhususkan untuk kehidupan sosial. Namun, para guru tampaknya sepenuhnya dikhususkan untuk pekerjaan mereka dan menghabiskan banyak waktu untuk memuaskan mereka. Menurut Halpin dan Silver sebagaimana dikutip oleh Rapti (2013) menyatakan bahwa kepala sekolah biasanya menjaga jarak dari guru, siswa dan orang tua untuk menghindari tingkat keakraban. Orang tua tidak dianjurkan untuk mengunjungi sekolah dan melihat guru tentang masalah anak-anak mereka, menggunakan waktu seperti itu pada sesuatu yang jauh lebih berharga (berdasarkan pendapat mereka). 
Iklim otonom lebih menggambarkan pada suasana di mana para guru memiliki tingkat kebebasan yang cukup untuk bertindak di sekolah. Pemimpin melambangkan model antusiasme dan semangat. Tidak ada ancaman atau pengaruh eksternal. Guru memiliki keinginan yang kuat untuk mengajar dan siswa termotivasi untuk belajar (Abdul Hamid Wahid, 2018). Ada hubungan erat antara manajer, guru, siswa dan orang tua.

Iklim keayahan dideskripsikan oleh suatu jenis atmosfer di mana kepala sekolah adalah orang yang bekerja keras, tetapi ia tidak memiliki dampak apa pun pada staf; bagi mereka label "pekerja keras" bukanlah kata yang akrab. Ada tingkat kedekatan antara pemimpin dan guru, tetapi harapan guru cenderung tidak praktis. Kepala sekolah penuh kehidupan, tetapi gaya manajemennya cenderung bersandar pada sisi otokratis. Akibatnya, mayoritas guru, siswa, dan orang tua lebih suka menjaga jarak mereka dari pemimpin.

Iklim sekolah Familier akrab digambarkan sebagai semacam atmosfer "laissez-faire" (biarkan mereka melakukannya). Kepala sekolah cukup menjaga suasana sosial yang mendukung pemenuhan tugas tertentu (Fathorrazi, 2017). Iklim Tertutup dideskripsikan biasanya para anggota bersikap acuh tak acuh atau masa bodoh. Organisasi tidak maju, semangat kerja kelompok rendah, karena para anggota di samping tidak memenuhi tuntutan pribadi, juga tidak dapat memperoleh kepuasan dari hasil karya mereka. Adapun Kepemimpinan atasan terlihat sebagai pengawasan, kaku, tidak peduli, tidak simpatik dan memberikan dukungan yang rendah. Bahkan pimpinan menunjukan kecurigaan, kurangnya perhatian terhadap guru, tertutup, kurang fleksible, apatis dan tidak komitmen.

\section{Faktor-Faktor yang Mempengaruhi Iklim Organisasi}

Menurut Higgins (1994) terdapat empat faktor yang mempengaruhi iklim organisasi di sekolah, yaitu; Pertama, Manajer/pimpinan. Pada dasarnya setiap tindakan yang diambil oleh pimpinan atau manajer mempengaruhi iklim dalam beberapa hal, seperti aturan-aturan, kebijakan-kebijakan, dan prosedurprosedur organisasi seperti masalah-masalah yang berhubungan dengan personalia, distribusi imbalan, gaya komunikasi, dan lain-lain. Kedua,Tingkah laku karyawan. Tingkah laku karyawan mempengaruhi iklim melalui kepribadian mereka, terutama kebutuhan mereka dan tindakan-tindakan yang mereka lakukan untuk memuaskan kebutuhan tersebut. Komunikasi karyawan memainkan bagian penting dalam membentuk iklim.

Ketiga, Tingkah laku kelompok kerja. Terdapat kebutuhan tertentu pada kebanyakan orang dalam hal hubungan persahabatan, suatu kebutuhan yang seringkali dipuaskan oleh kelompok dalam organisasi. Kelompok-kelompok berkembang dalam organisasi dengan dua cara, yaitu secara formal, utamanya pada kelompok kerja; dan informal, sebagai kelompok persahabatan atau kesamaan minat. 
Al-Tanzim : Jurnal Manajemen Pendidikan Islam E-ISSN: 2549-5720 P-ISSN: 2549-3663

Vol. 03 No. 02 (2019) : 61-72

https:// ejournal.unuja.ac.id/index.php/al-tanzim

Keempat, Faktor eksternal organisasi. Sejumlah faktor eksternal organisasi mempengaruhi iklim pada organisasi tersebut. Keadaan ekonomi adalah faktor utama yang mempengaruhi iklim. Contohnya dalam perekonomian dengan inflasi yang tinggi, organisasi berada dalam tekanan untuk memberikan peningkatan keuntungan sekurang-kurangnya sama dengan tingkat inflasi. Seandainya pemerintah telah menetapkan aturan tentang pemberian upah dan harga yang dapat membatasi peningkatan keuntungan, karyawan mungkin menjadi tidak senang dan bisa keluar untuk mendapatkan pekerjaan pada perusahaan lain. Di lain pihak, ledakan ekonomi dapat mendorong penjualan dan memungkinkan setiap orang mendapatkan pekerjaan dan peningkatan keuntungan yang besar, sehingga hasilnya iklim menjadi lebih positif

\section{Menciptakan Iklim yang Positif}

Iklim sekolah yang positif sering dicirikan oleh hubungan yang kuat antara siswa dan staf. Disiplin formal yang diberikan tidak bersifat menghukum dengan ukuran apapun, tetapi sesuai dengan konsekuensinya; peluang keterlibatan, penilaian dan manajemen untuk siswa dalam berbagai kegiatan.

Iklim sekolah dapat dilihat di setiap aspek lain, yaitu; dari cara bagaimana guru berperilaku, data atas partisipasi siswa di kelas, dalam pelaksanaan program, selama liburan, di ruang bersama guru, dari gerakan siswa di lorong dan dari pola komunikasi mereka, dan lain-lain.

Untuk menciptakan iklim positif, sekolah berfokus pada beberapa area. Ia terlibat dalam serangkaian inisiatif sebagaimana diuraikan dalam diagram "Pengembangan hubungan yang sehat dan saling menghormati di antara anggota komunitas sekolah" yang digambarkan dalam bagan di bawah ini:

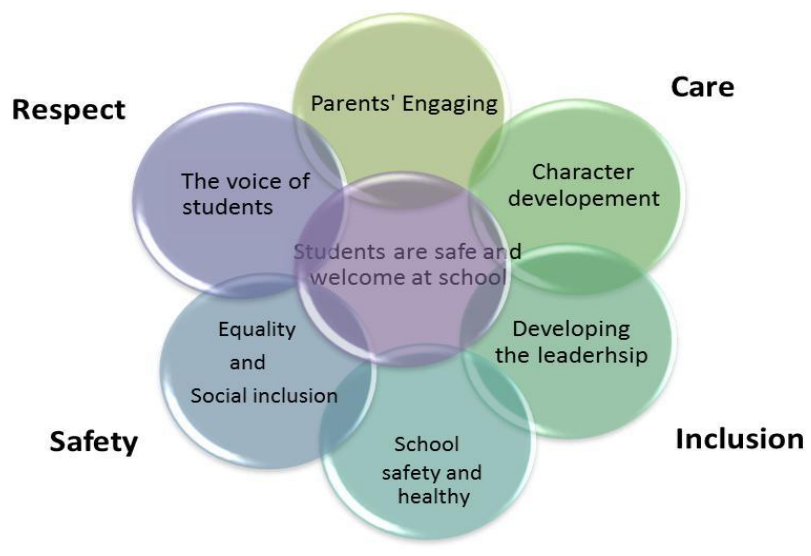

Gambar 1 :

Pengembangan hubungan yang sehat di sekolah 
Beberapa prinsip panduan mengenai implementasi inisiatif ini, yaitu; pertama, setiap stakeholder memiliki peran dalam membangun iklim yang ramah, positif dan inklusif di sekolah. Kedua, pembangunan iklim sekolah yang positif mengharuskan fokusnya dipersempit pada pengembangan hubungan yang kuat dan menghormati seluruh komunitas sekolah. Ketiga, membangun iklim sekolah yang positif berarti menanamkan prinsip kesetaraan dan inklusi dalam semua aspek lingkungan pembelajaran untuk mendukung kesejahteraan dan prestasi akademik semua siswa. Keempat, tidak ada solusi tunggal yang dapat diresepkan untuk menjamin pembentukan dan pemeliharaan iklim sekolah yang positif. Sukses membutuhkan upaya berkelanjutan yang harus komprehensif dan kooperatif dari semua pemangku kepentingan dengan kepentingan di sekolah.

Iklim sekolah dapat dengan mudah dimanipulasi dan dengan demikian secara langsung mempengaruhi perilaku orang yang terkait dengan sekolah. Mereka menunjukkan bahwa kriteria kunci untuk pembentukan iklim positif di sekolah adalah; a) kepuasan kerja, b) pengakuan martabat manusia serta kerja sama tim.

\section{Peningkatan dan Pemeliharaan Iklim Organisasi yang positif}

Menurut Rapti (2013), kepala sekolah, guru, siswa dan orang tua memiliki banyak peluang yang tersedia untuk memperbaiki iklim sekolah. Berikut ini indikator dalam meningkatkan iklim organisasi; Pertama, pelaksanaan karakter utama dan misi pendidikan serta promosi nilai-nilai moral dasar dalam siswa. Kedua, keterlibatan dan komitmen komunitas sekolah (guru, siswa dan orang tua) dalam pekerjaannya. Ketiga, pencegahan kekerasan dan konflik di sekolah. Keempat, peer kolaborasi. Kelima, larangan kekerasan verbal dan psikologis. Keenam, Kepala sekolah dan guru memperlakukan siswa secara adil, setara dan dengan hormat. Ketujuh, Lingkungan yang aman untuk staf dan siswa dijamin. Kedelapan, Penguatan kepribadian siswa melalui kegiatan.

Setelah upaya peningkatan, perlu adanya upaya pemeliharaan iklim organisasi. Berikut ini cara yang ditawarkan Freiberg dan Stein sebagaimana dikutip oleh Rapti (2013) menyatakan bahwa; dalam memelihara iklim sekolah yang harus dilakukan meliputi: Pertama, motivasi. Kepala sekolah diberikan banyak peluang untuk menggunakan emosi (yang sudah ada di sekolah) secara konstruktif untuk membuat para guru, siswa dan orang tua terlibat secara mendalam dengan mendorong motivasi, komitmen pribadi terhadap kegiatan sekolah mereka dalam mencapai tujuan. Kedua, evaluasi. Agar dapat mempertahankan iklim positif, manajer sekolah (kepala sekolah) harus tahu dan kemudian mengevaluasi kinerja guru untuk meningkatkan efektivitas proses pengajaran. Evaluasi rutin kinerja guru berfungsi sebagai sarana untuk meningkatkan proses pengajaran dan mempromosikan iklim sekolah yang positif. Ketiga, pengembangan guru/karyawan. Sekolah harus diubah menjadi 
Al-Tanzim : Jurnal Manajemen Pendidikan Islam E-ISSN: 2549-5720 P-ISSN: 2549-3663

Vol. 03 No. 02 (2019) : 61-72

https:// ejournal.unija.ac.id/index.php/al-tanzim

organisasi pembelajaran, tempat di mana kapasitas siswa dan guru diciptakan dan didorong. Sekolah adalah organisasi yang berkomitmen pada proses belajar mengajar, karena itu adalah tujuan sekolah. Oleh karena itu, sama seperti siswa meningkatkan pengetahuan mereka secara terus menerus, dengan cara yang sama para guru perlu mengembangkan pengetahuan mereka serta potensi profesional mereka. Keempat, kerja tim. Sebuah tim sebagai sekelompok orang yang memiliki keterampilan tertentu yang bekerja sama untuk mencapai tujuan bersama yang menjadi tanggung jawab mereka secara kolektif. Dengan kata lain, kerja sama tim terjadi ketika para guru bekerja bersama untuk tujuan yang sama dan menggunakan keterampilan mereka untuk mencapai target bersama.

\section{MENGEMBANGKAN IKLIM ORGANISASI DENGAN MENGGUNAKAN MODEL TAGIURI}

Konsep yang ditawarkan Tagiuri tentang iklim organisasi mendapatkan perhatian dari Stringer (1968), kemudian dijabarkan melalui rumusan operasional dengan memasukkan delapan dimensi dan telah diterapkan menjadi rangkaian empat buah penelitian mereka, yang dijelaskan sebagai berikut; Pertama, struktur. Struktur ini menjelaskan tentang tingkat penjenjangan serta tugas dan wewenang yang harus dilaksanakan. Konsep struktural ini secara langsung berfungsi dan menjadi tanggungjawab anggota pada masing-masing bidang dan tugas yang diembannya.

Kedua, kehangatan dan dukungan. Karyawan baru yang mendapatkan banyak dukungan dan bantuan dari lingkungan kerjanya, cenderung akan memiliki rasa empati, kebersamaan, dan sifat loyal pada organisasi. Jadi, iklim kerja yang di dalamnya terdapat sikap kehangatan dan saling mendukung sangatlah penting bagi perkembangan suatu organisasi.

Ketiga, Tantangan dan tanggungjawab. Faktor tantangan lebih mengarah pada perkembangan semangat untuk mengejar prestasi tinggi di kalangan karyawan. Semangat karyawan untuk berprestasi akan tumbuh subur apabila tanggung jawab yang diemban oleh organisasi lebih besar.

Keempat, konflik, merupakan persepsi perbedaan kepentingan dan persaingan antarpribadi dan unit kerja yang biasa terjadi pada karyawan. Solusi yang ditawarkan pemimpin sangat berpengaruh pada efektivitas dan integrasi organisasi. Berkaitan dengan hal ini, konflik dan resolusi konflik bisa dijadikan sebagai petunjuk untuk dinamika perkembangan organisasi.

Kelima, ganjaran dan hukuman. Ukuran persepsi tentang situasi yang butuh sebuah penegasan tentang pelaksanaan ganjaran atau sanksi. Singkatnya, integrasi segenap karyawan disuatu lembaga perlu dijunjung tinggi sebagai nilai yang dapat meningkatkan kinerja organisasi.

Keenam, identitas organisasi sebagai ukuran loyalitas karyawan dalam organisasi. Ukuran loyalitas ini memiliki keterkaitan dengan keteguhan identitas dan perbaikan kinerja karyawan. 
Ketujuh, standar kinerja dan harapan, merupakan persepsi tentang pentingnya kejelasan tentang kinerja dan pengharapan dalam organisasi. Kedelapan, resiko dan pengambilan resiko. Hal ini lebih mengacu pada filosofi manajemen tentang peluang dan resiko selama proses pembuatan keputusan.

Dalam praktiknya pada dunia pendidikan di sekolah, setidaknya Tagiuri membagi taksonomi iklim sekolah menjadi empat dimensi, yaitu:

Pertama, ekologi. yang termasuk ekologi dalam iklim sekolah antara lain aspek-aspek fisik-material, seperti bangunan sekolah, ruang kepala sekolah, ruang guru, ruang perpustakaan, ruang bimbingan konseling siswa dan ruangan yang sejenisnya. Kedua, dimensi sosial, yang termasuk dimensi sosial dalam iklim sekolah seperti moral guru, latar belakang siswa, stabilitas staf dan sebagainya. Ketiga, sistem sosial. sistem ini berkaitan dengan struktur baik formal maupun informal atau berbagai aturan untuk mengendalikan interaksi baik individu maupun kelompok di sekolah, interaksi tersebut berbentuk komunikasi antara kepala sekolah-guru, hubungan antara guru-siswa, partisipasi staf ketika mengambil sebuah keputusan, ketertiban siswa dalam dalam hal mengambil keputusan, kolegialitas. Keempat, budaya. Budaya ini berupa sistem nilai dan keyakinan, seperti norma pergaulan siswa, ekspektasi keberhasilan, dan disiplin sekolah.

\section{KESIMPULAN}

Iklim organisasi memiliki peranan yang sangat penting untuk mencapai tujuan suatu organisasi. Karena dengan terbentuknya iklim yang positif, maka efektivitas sekolah akan terbangun. Iklim sekolah dikatakan positif apabila semua stakeholder memiliki persepsi yang sama terhadap kualitas perlakuan organisasi terhadap karyawan.

Untuk menciptakan iklim sekolah yang positif tentunya diperlukan hubungan sosial yang harmonis antara sesama pekerja. Hubungan sosial ini berupa komunikasi vertikal maupun horizontal, kerjasama karyawan saat bekerja, supervisi, dukungan dari bawahan, dan kejelasan tugas yang diemban oleh para pekerja. Dengan kata lain, iklim organisasi merupakan nilai-nilai, kepercayaan, tradisi, dan asumsi yang diberikan kepada para karyawan, baik yang diekspresikan maupun yang tidak diekspresikan. 
Al-Tanzim : Jurnal Manajemen Pendidikan Islam E-ISSN: 2549-5720 P-ISSN: 2549-3663

Vol. 03 No. 02 (2019) : 61-72 https:// ejournal.unuja.ac.id/ index.php/al-tanzim

\section{DAFTAR PUSTAKA}

Abdul Hamid Wahid, Chusnul Muali, D. (2018). Media dan Motivasi Belajar; Kritik Eksplanasi Konstruktif dalam Implementasi Strategi Pembelajaran. An-Nuha Vol., 5(1), 1-21.

Blanchard Kneth and Hersey Paul. (1988). Management of Organization Behavior. Singapore: Prentice Hall. Inc.

Burhanuddin, A. (1994). Analisis Administrasi Manajemen dan Kepemimpinan Pendidikan. Jakarta: Bumi Aksara.

David Thenuwara Gamage, N. S.-K. P. (2003). Leadership and Management in Education: Developing Essential Skills and Competencies. Hongkong: The Chinese University Press.

Fathorrazi, A. (2017). Kepemimpinan Kepala Sekolah Dalam Implementasi Dan Pengembangan Kurikulum 2013. Al-Tanzim : Jurnal Manajemen Pendidikan Islam, 1(1), 56-63.

Gibson, James L., John M. Ivancevich and James H. Donnelly, J. (2009). Organization Behavior: Structure, Process. New York: McGraw-Hil.

Griffin, M. dan. (2013). Perilaku Organisasi. Jakarta: Salemba Empat.

Haryani, E. (2017). Pengaruh Iklim Organisasi Sekolah dan Kepemimpinan Kepala Sekolah terhadap Manajemen Pembelajaran untuk Mewujudkan Kinerja Guru. Jurnal Pendidikan Universitas Garut, 11(1), 77-87.

Higgins. (1994). Hubungan Antara Kepemimpinan dengan Iklim Organisasi dan Kepuasan Kerja. Jakarta: PPM.

Hoy, K. W., dan C. G. M. (2001). Education Administration: Theory, Research, and Practice. Singapure: Mc Graw-Hill Co.

Kiki Cahaya Setiawan Prodi. (2015). Pengaruh Iklim Organisasi Terhadap Kinerja Karyawan Level Pelaksana di Divisi Operasi PT. Pusri Palembang. $\quad$ PSIKIS-Jurnal Psikologi Islami, 1(1), 23-32. https://doi.org/10.1017/CBO9781107415324.004

Luthans, F. (1995). Organizational Behavior. New York: McGraw Hill International.

Muhammad Husni, H. P. (2018). Membangun Budaya Organisasi Berbasis Religius. Al-Tanzim : Jurnal Manajemen Pendidikan Islam, 2(1), 64-79.

Rapti, D. (2013). School Climate as an Important Component in School Effectiveness. Academicus International Scientific Journal, Entrepreneurship Training Center Albania, (8), 110-125. 
Redding, W. C. (1972). Commnication within in the Organization: An Interpretive of Theory and Research. New York: Industrial Communication Council.

Robbins, S. (1996). Organizational Behavior. New Jersey, 1996). Hal 4: Prentice Hall.

Stringer, G. H. L. dan R. (1968). Motivation and Organizational Climate. Boston: Division of Research, Harvard University.

Tagiuri, R. (1968). Organizational Climate: Explorations of a Concept. Boston: Harvard University.

Tubbs, J. Eric., Garner, M. (2008). Impact Of School Climate On School Outcomes. Journal of College Teaching \& Learning, 5(9), 17-26.

Yukl, G. (2015). Kepemimpinan Dalam Organisasi. Jakarta: Indeks. 